\title{
Depression and Associated Factors Among Adult HIV/AIDS Patients Attending Antiretroviral Therapy at Wolaita Sodo University Teaching and Referral Hospital, Southern Ethiopia
}

This article was published in the following Dove Press journal:

HIVIAIDS - Research and Palliative Care

\author{
Abera Beyamo (iD) \\ Terefu Bashe ${ }^{2}$ \\ Wolde Facha (iD ${ }^{3}$ \\ Tezera Moshago $\left(\mathbb{D}^{3}\right.$ \\ 'Department of Public Health, Wachemo \\ University, Hossana, Ethiopia; \\ ${ }^{2}$ Department of Pharmacy, Wolaita Sodo \\ University Teaching and Referral \\ Hospital, Wolaita Sodo, Ethiopia; ${ }^{3}$ School \\ of Public Health, College of Health \\ Sciences and Medicine, Wolaita Sodo \\ University, Wolaita Sodo, Ethiopia
}

\begin{abstract}
Background: Nearly, 350 million people in the world are currently living with depression. Depression happening in PLHIV leads to alteration of economic productivity, decrease of working abilities, social isolation, physical decline and difficulties in solving problems. This study investigates the burden of depression and associated factors on HIV/AIDS patients attending an ART clinic.
\end{abstract}

Methods: An institution-based cross-sectional study was implemented from April 1 to May 30, 2019 on a total of 417 HIV-positive patients. Systematic random sampling technique was used to access the study participants. Interviewer-administered structured questionnaire was used for data collection. Data were entered in to EpiData 3.1 and then were exported into Statistical Package for the Social Sciences (SPSS window version 20) for analysis.

Results: Four hundred ten (410) respondents participated in the study with a response rate of 98.3\%. The burden of depression was $50.5 \%$ in this study. Male (AOR=1.53; 95\%CI: $1.016-$ $2.311)$, people living in urban $(\mathrm{AOR}=2.20 ; 95 \% \mathrm{CI}: 1.29-3.75)$, patients who had opportunistic infection $(\mathrm{AOR}=1.98$; 95\%CI: 1.27-3.11), poor medication adherence $(\mathrm{AOR}=1.79$; 95\%CI: 1.13-2.85) and high HIV-related perceived stigma (AOR=1.66; 95\%CI: $1.04-2.67)$ were more likely depressed compared to their counterparts.

Conclusion: In this study, male sex, those patients living in urban areas, having opportunistic infections, poor medication adherence, and high HIV-related perceived stigma were significantly associated with depression. Hence, organizations working on HIV programs should address these factors to prevent and manage depression among HIVpositive patients.

Keywords: prevalence, depression, HIV/AIDS, Wolaita Sodo University

\section{Introduction}

Depression is a common mental disorder that presents with depressed mood, loss of interest or pleasure, decreased energy, feelings of guilt or low self-worth, disturbed sleep or appetite, and poor concentration. ${ }^{1}$ These problems can become chronic or recurrent and lead to substantial impairment in an individual's ability to take care of their everyday responsibilities. ${ }^{2}$

The burden of mental health problems in HIV-infected individuals is significantly higher than that in the general population. Psychiatric complications of HIV/ AIDS signify a considerable additional burden for mental health services and
Correspondence: Abera Beyamo PO Box: 667, Hosaena, Ethiopia Tel +25I 92337I542

Fax +25I 465551910

Email bdereje05@gmail.com 
professionals in less affluent countries with high HIV prevalence rates. ${ }^{3}$ Psychological stress and progression of HIV infection have been associated with a lower quality of life. Moreover, depression has been associated with poorer adherence to antiretroviral treatment (ART). ${ }^{4}$

Mental disorders and HIV/AIDS are closely interlinked. Mental disorders are associated with an increased risk of HIV/AIDS infection and interfere with the treatment; conversely some mental disorders occur as direct result of HIV infection. ${ }^{5}$ Depression contributes significantly to disease morbidity and affects people in all communities across the globe. ${ }^{6}$ It affects an individual's ability to comply with HIV/ AIDS treatment, as well as quality of life and lifespan. ${ }^{7}$

Moreover, depression has great impact on the quality of life of persons living with HIV/AIDS. Depression has been also reported as one of the main causes of poor adherence with antiretroviral regimens. Histories of depression and anxiety both frequently coexisted in patients; in fact, all patients who reported having a history of depression diagnosis also had a history of anxiety diagnosis. ${ }^{8}$ The burden of depressive disorders in HIV-infected patients ranges from $12 \%$ to $66 \%$ and is undiagnosed in $50 \%$ to $60 \%$ of these patients. ${ }^{9}$

However, the existing information on the burden of depression and the factors associated with depression in a population of PLWHA is scarce in Ethiopia. Therefore, this study aimed to assess prevalence of depression and associated factors among HIV/AIDS patients taking anteretroviral therapy in ART clinic at Wolaita Sodo University Teaching and Referral Hospital, Sodo Ethiopia.

\section{Materials and Methods Study Area and Period}

The study was conducted in Wolaita Sodo University Teaching and Referral Hospital, Sodo town from April 1 to May 30, 2019. Currently, Sodo town has three sub-cities and had an estimated total population of 140,195 for the year 2018 according to 2007 central statistical agency (CSA). Wolaita Sodo University Teaching and Referral Hospital is the only referral hospital in Wolaita zone and serves for about three million people in different outpatient and inpatient departments from parts of neighboring zones and regions. The hospital was established as a clinic in Sodo town, Ottona village in 1928 by missionaries and served as district to general and attained referral hospital status on September 2013. It has 347 beds and 12 staff who were providing service for 4,362 ART patients.

\section{Study Design}

An institution-based cross-sectional study design was employed in Wolaita Sodo University Teaching Referral Hospital ART clinic.

\section{Source Population}

Source population was all adults (aged $\geq 15$ years old) patients infected with HIV and receiving ART in Wolaita Sodo University Teaching Referral Hospital ART clinic.

\section{Study Population}

All adults (age $\geq 15$ years old) patients infected with HIV and receiving ART in Wolaita Sodo University teaching Referral Hospital ART clinic during the data collection period.

\section{Inclusion and Exclusion Criteria}

Inclusion Criteria

Patients whose age were $\geq 15$ years and stayed greater than or equal to one month on ART were included in our study.

\section{Exclusion Criteria}

Those patients who were critically ill were excluded from the study.

\section{Variables \\ Dependent variables \\ Depression}

\section{Independent Variables}

Sociodemographic factors (age, sex, residence, marital status, ethnicity, religion, educational status, occupation status, monthly income, etc).

Clinical and psychosocial characteristics (CD4 cell count (cells $/ \mathrm{mm}^{3}$ ), viral load (copies/dL), WHO HIV/ AIDS stage, presence of opportunistic infection, social stigma, social support).

Drug-related factors (adherence, CPT prophylaxis, INH prophylaxis).

\section{Operational Definition Depression}

The study participants who scored PHQ-9 score $\geq 5$ were considered depressed and those who scored $<5$ were not depressed. ${ }^{10}$.

\section{HIV-related Perceived Stigma}

The respondents who scored $\geq 2.5$ from a five-point HIV stigma scale were considered stigmatized and those who scored $<2.5$ were not stigmatized. ${ }^{11}$ 


\section{Social Support}

The respondents who scored 3-8 on the Oslo three-item social support scale were categorized as having poor support, 9-11 were categorized as having moderate support, and $12-14$ were categorized as having strong support. ${ }^{12}$

\section{Adherence}

The respondents who take $\geq 95 \%$ of prescribed medications correctly were classified as having good adherence, $85-94 \%$ fair adherence and $<85 \%$ were classified as having poor adherence. ${ }^{13}$

\section{Sample Size}

The sample size was calculated for each objective. We take the calculated sample for second objective because it gives a greater sample. Sample size for the second objective was calculated by using perceived stigma as independent predictor with $(\mathrm{AOR}=2.83 ; 95 \% \mathrm{CI}: 1.78$ 4.48), 0.05 margin of error, $80 \%$ power, $43.9 \%$ anticipated proportion taken from the study conducted in Hawassa, Ethiopia $^{14}$ and $10 \%$ nonresponse rate. The final sample size was 417 .

\section{Sampling Technique}

Systematic sampling technique was used to select the study participants. Sampling interval was determined by dividing 1335 who were the total adult population on ART to the total sample size of 417 . Thus the $\mathrm{k}$ value is three and from the first three ART patients, the second patient was randomly selected and then every third patient was included in the study.

\section{Data Collection Procedure and Instruments}

Two BSc nurses who were working not in the ART clinic and with greater than two years work experience were recruited for data collection, one MSc in health was assigned as supervisor. The questionnaire contains sociodemographic characteristics, Oslo three-item social support scale, HIVrelated perceived stigma scale and patient health questionnaires item nine (PHQ-9) and the data was collected by interviewing ART patients. The questionnaire also contains CD4 cell count, WHO HIV/AIDS stage, presence of opportunistic infection, duration on ART treatment, viral load, medication adherence, CPT prophylaxis, INH prophylaxis and these data were collected from the patient card.

\section{Data Quality Control}

The pretest was conducted on $5 \%$ of total sample at the Christian hospital. Training was given for data collectors and supervisor on the data collection tool and sampling techniques. Daily supervision was held regularly during data collection period. The collected data were checked on a daily basis for completeness and consistency.

\section{Data Management and Analysis Procedure}

The data was entered into EpiData 3.1 and exported into Statistical Package for the Social Sciences (SPSS Windows version 20) for analysis. Descriptive summary using frequencies, proportions, graphs and cross tabs was used to present results of the study. Variables with a $p$-value of less than 0.25 in the bivariate analysis were entered into the multivariate analysis. Those variables having $p$-value of $<0.05$ were considered statistically significant. Adjusted odds ratio with $95 \% \mathrm{CI}$ was calculated to determine association. Multicollinearity was checked among selected independent variables using the variance inflation factor and none was found. In addition, goodness of fit of the final model was checked and found fit by the Hosmer-Lemeshow test.

\section{Results}

\section{Sociodemographic Characteristics of the Study Participants}

Among 417 sampled patients taking treatment in the ART clinic, 410 were included in the study, with a response rate of $98.3 \%$. The mean age $( \pm \mathrm{SD})$ of the respondents was $33.05( \pm 9.341)$ years. The majority of the study participants, $233(56.8 \%)$ were female, 320 (78\%) were aged between 25 and 49 years, 330 (80.5\%) were living in urban areas, 307 (74.9) were living in Wolaita, 229 $(55.9 \%)$ were protestant religion followers and 267 (65.1\%) were married. Among participants, 166 (40.5\%) attended second cycle education and $131(32 \%)$ were privately employed. The average income of the respondents per month was 500.00 Ethiopian birr (Table 1).

\section{Clinical Characteristics of the Study Participants}

From patients who were following treatment in ART clinic, a maximum CD4 cell count was 1591 with a mean of 517.78. The majority of respondents, 228 
Table I Sociodemographic Characteristics of Patients Living with HIVIAIDS at Wolaita Sodo University Teaching and Referral Hospital ART Clinic, $2019(n=410)$

\begin{tabular}{|c|c|c|c|}
\hline Characteristics & Category & Frequency & Percent \\
\hline \multirow[t]{2}{*}{ Sex } & Male & 177 & 43.2 \\
\hline & Female & 233 & 56.8 \\
\hline \multirow[t]{4}{*}{ Age } & $15-24$ & 61 & 14.9 \\
\hline & $25-49$ & 320 & 78.0 \\
\hline & $50-64$ & 27 & 6.6 \\
\hline & $\geq 65$ & 2 & 0.5 \\
\hline \multirow[t]{2}{*}{ Residence } & Urban & 330 & 80.5 \\
\hline & Rural & 80 & 19.5 \\
\hline \multirow[t]{4}{*}{ Marital status } & Married & 267 & 65.1 \\
\hline & Unmarried & 82 & 20.0 \\
\hline & Divorced & 38 & 9.3 \\
\hline & Widowed & 23 & 5.6 \\
\hline \multirow[t]{2}{*}{ Ethnicity } & Wolaita & 307 & 74.9 \\
\hline & Others & 103 & 25.1 \\
\hline \multirow[t]{3}{*}{ Religion } & Protestant & 229 & 55.9 \\
\hline & Orthodox & 161 & 39.3 \\
\hline & Others & 20 & 4.9 \\
\hline \multirow[t]{6}{*}{$\begin{array}{l}\text { Educational } \\
\text { status }\end{array}$} & $\begin{array}{l}\text { Unable to read and } \\
\text { write }\end{array}$ & 20 & 4.9 \\
\hline & Read and write & 34 & 8.3 \\
\hline & $\begin{array}{l}\text { First cycle (Grade } \\
\mid-4)\end{array}$ & 41 & 10 \\
\hline & $\begin{array}{l}\text { Second cycle (Grade } \\
5-8)\end{array}$ & 166 & 40.5 \\
\hline & $\begin{array}{l}\text { High school and } \\
\text { preparatory (Grade } \\
9-12)\end{array}$ & 111 & 27.1 \\
\hline & $\begin{array}{l}\text { Tertiary education } \\
\text { (Above Grade I2) }\end{array}$ & 38 & 9.3 \\
\hline \multirow{7}{*}{$\begin{array}{l}\text { Occupation } \\
\text { status }\end{array}$} & Merchant & 54 & 13.2 \\
\hline & $\begin{array}{l}\text { Government } \\
\text { employed }\end{array}$ & 49 & 12.0 \\
\hline & Privately employed & $13 \mid$ & 32 \\
\hline & Day laborer & 67 & 16.3 \\
\hline & Student & 45 & 11.0 \\
\hline & Housewife & 50 & 12.2 \\
\hline & Jobless & 14 & 3.4 \\
\hline \multirow{4}{*}{$\begin{array}{l}\text { Average monthly } \\
\text { Income (ETB) }\end{array}$} & $\leq 500$ & 215 & 52.4 \\
\hline & $50 I-1000$ & 78 & 19 \\
\hline & $1001-1500$ & 17 & 4.1 \\
\hline & $\geq|50|$ & 100 & 24.4 \\
\hline
\end{tabular}

(55.6\%) had CD4 cell counts ranged between 351 and $1000\left(\right.$ cells $\left./ \mathrm{mm}^{3}\right)$. Most of participants, $329(80.2 \%)$ had viral load less than 1000 (copies/dL), 384 (93.8\%) were on
ART for longer than 12 months, 331 (80.7\%) were stage I HIV/AIDS, 264 (64.4\%) had no opportunistic infections, 219 (53.4\%) had good ART adherence, 279 (68\%) had no cotrimoxazole prophylaxis, $383(93.4 \%)$ had no isoniazid prophylaxis, 257 (62.7\%) had poor social support and 285 (69.5\%) had low perceived stigma (Table 2).

\section{Prevalence of Depression Among the Study Participants}

The burden of depression was found to be 208 (50.5\%) (Figure 1).

\section{Factors Associated with Depression in Bivariate Analysis}

The candidate variables on bivariate analysis for multivariable were sex, residence, marital status; educational

Table 2 The Clinical and Psychosocial Factors Among People Living with HIVIAIDS at Wolaita Sodo University Teaching and Referral Hospital ART Clinic, $2019(n=410)$

\begin{tabular}{|c|c|c|c|}
\hline Characteristics & Category & Frequency & Percent \\
\hline \multirow[t]{3}{*}{ CD4 cell counts } & $\leq 350$ & 160 & 39.0 \\
\hline & $35 I-1000$ & 228 & 55.6 \\
\hline & $>1000$ & 22 & 5.4 \\
\hline \multirow[t]{2}{*}{ Viral load (copies/dL) } & $\leq 1000$ & 329 & 80.2 \\
\hline & $>1000$ & 81 & 19.8 \\
\hline \multirow[t]{2}{*}{ Duration on ART } & $\leq 12$ months & 26 & 6.3 \\
\hline & $>12$ months & 384 & 93.7 \\
\hline \multirow[t]{4}{*}{ WHO HIVIAIDS stage } & I & 331 & 80.7 \\
\hline & ॥ & 20 & 4.9 \\
\hline & III & 44 & 10.7 \\
\hline & IV & 15 & 3.7 \\
\hline \multirow[t]{2}{*}{ Opportunistic infection } & Yes & 146 & 35.6 \\
\hline & No & 264 & 64.4 \\
\hline \multirow[t]{3}{*}{ Adherence } & Good & 219 & 53.4 \\
\hline & Fair & $4 I$ & 10.0 \\
\hline & Poor & 150 & 36.6 \\
\hline \multirow[t]{2}{*}{ CPT prophylaxis } & Yes & $|3|$ & 32.0 \\
\hline & No & 279 & 68.0 \\
\hline \multirow[t]{2}{*}{ INH prophylaxis } & Yes & 27 & 6.6 \\
\hline & No & 383 & 93.4 \\
\hline \multirow[t]{3}{*}{ Social support } & Poor & 257 & 62.7 \\
\hline & Moderate & 109 & 26.6 \\
\hline & Strong & 44 & 10.7 \\
\hline \multirow[t]{2}{*}{ Perceived social stigma } & High & 125 & 30.5 \\
\hline & Low & 285 & 69.5 \\
\hline
\end{tabular}




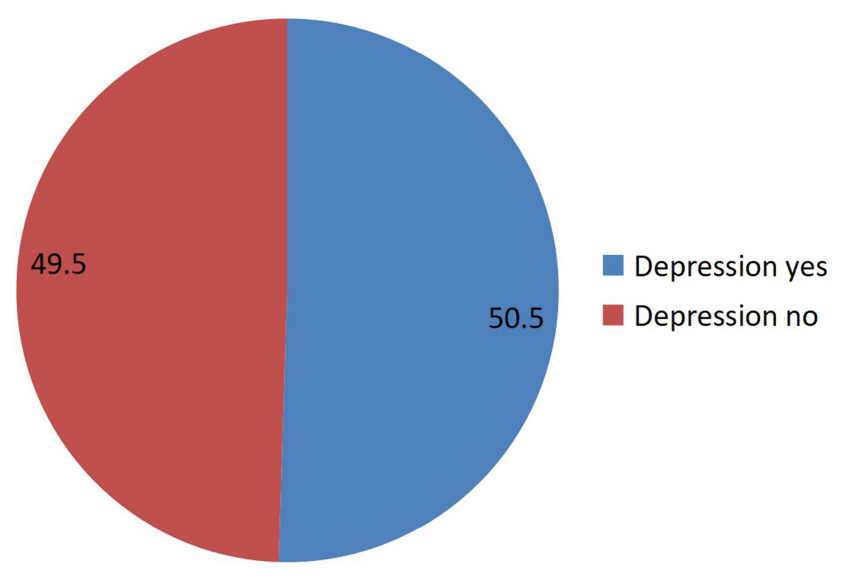

Figure I The burden of depression among people living with HIVIAIDS attending Wolaita Sodo University Teaching and Referral Hospital, Southern Ethiopia, 2019.

status, occupation status, average monthly income, CD4 count, viral load, WHO HIV/AIDS stage, opportunistic infection, medication adherence, CPT prophylaxis and social stigma were a candidate for multiple logistic regressions (Table 3).

\section{Factors Associated with Depression Among People Living with HIV}

An adjusted multivariable model was created by forward stepwise logistic regression using the factors that were significant with the bivariate model. In our study males were 1.5 times more likely to develop depression than females ( $\mathrm{AOR}=1.53$; 95\% $\mathrm{CI}$ : 1.02-2.31). Individuals living in urban areas were twice as likely to develop depression than those who were living in rural areas $(\mathrm{AOR}=2.20$; 95\%CI: 1.30-3.75). Patients who had opportunistic infections were 1.9 times more likely exposed to depression compared to those patients who had no opportunistic infections $(\mathrm{AOR}=1.99 ; 95 \% \mathrm{CI}$ : 1.27-3.11). Those with poor medication adherence were 1.7 times more likely to develop depression compared to those with good medication adherence $(\mathrm{AOR}=1.79 ; 95 \% \mathrm{CI}$ : 1.13-2.85). Patients having high HIV-perceived stigma were 1.6 times more likely to become depressed compared to patients who had low perceived stigma $(\mathrm{AOR}=1.67$; $(95 \% \mathrm{CI}$ : $1.04-2.67)$ (Table 4).

\section{Discussion}

This study revealed that the burden of depression was $50.5 \%$. When compared with depression in the general population, which is $17.5 \%,{ }^{15}$ the prevalence is higher among HIV/AIDS patients. The possible reason might be that these groups are more at risk for developing depression due to stigma. The current study finding is in line with other studies carried out in Southern Brazil, China, Harer and Hawassa, which ranged from $48.5 \%$ to $53.5 \%$. ${ }^{14,16-18}$ The current study finding was lower than astudy done in Sudan, $63.1 \%{ }^{19}$ The variation in prevalence might be due to difference in sociocultural situation. This study finding is higher than the findings in India, Myanmar, Jamaica, Cameroon, Malawi, pooled prevalence in Ethiopia, Tigray, Debremarkos, Debrebiran, Yekatit 12, in which prevalence was reported from $11.7 \%$ to $43.9 \% .^{20-29}$ The variation might be due to data collection instruments, and study participant's difference.

This finding shows that males living with HIV were about 1.5 times more likely to develop depression compared to females. The finding disagrees with other studies conducted in rural South Africa and Sudan such that females were more likely to develop depression compared to males. ${ }^{19,30}$ In addition, this is similar to a study conducted in Harer town assessing depression in a population of HIV infected people. ${ }^{18}$ People living in urban areas were about 2.2 times more likely to develop depression compared to people living in rural areas. This was supported by research conducted in Tigray and rural South Africa. $^{26}$

Sleep is one of the most important protective factors for good mental health. And yet cities can erode sleep patterns with increased ambient noise and light pollution, and potentially with crowding. Socioeconomic status is the risk factor in urban areas most associated with mental health, especially depression. Job loss and low income were greatly associated with depression, because if an individual loses their work, they suffer even for basic life needs.

Individuals with opportunistic infection were about twice as likely to develop depression compared to individuals without opportunistic infection. This is in line with the finding in East Africa. ${ }^{11}$ This might be due to opportunistic infection leading to dissatisfaction with one's physical appearance, which might be a reason for the occurrence of depression.

Having poor medication adherence was about twice as likely to develop depression compared with those who had good medication adherence. The finding is similar to a study conducted in the Southwest Regional Hospital of Cameron. This might be due to the fact that if the patients did not adhere to medication, they miss one or more doses and experience loss of follow-up and developed resistance 
Table 3 Factors Associated with Depression in Bivariate Analysis Among People Living with HIV/AIDS at Wolaita Sodo University Teaching and Referral Hospital ART Clinic, $2019(n=410)$

\begin{tabular}{|c|c|c|c|c|c|}
\hline \multirow[t]{2}{*}{ Characteristics } & \multirow[t]{2}{*}{ Category } & \multicolumn{2}{|c|}{ Depression } & \multirow[t]{2}{*}{ COR $(95 \% \mathrm{Cl})$} & \multirow[t]{2}{*}{$p$-value } \\
\hline & & Yes & No & & \\
\hline Sex & $\begin{array}{l}\text { Male } \\
\text { Female }\end{array}$ & $\begin{array}{l}79 \\
128\end{array}$ & $\begin{array}{l}98 \\
105\end{array}$ & $\begin{array}{l}1.51(1.02-2.24) \\
1\end{array}$ & $0.039 *$ \\
\hline Residence & $\begin{array}{l}\text { Urban } \\
\text { Rural }\end{array}$ & $\begin{array}{l}155 \\
52\end{array}$ & $\begin{array}{l}175 \\
28\end{array}$ & $\begin{array}{l}2.10(1.26-3.48) \\
1\end{array}$ & $0.004 *$ \\
\hline Marital status & $\begin{array}{l}\text { Others } \\
\text { Divorced } \\
\text { Unmarried } \\
\text { Married }\end{array}$ & $\begin{array}{l}11 \\
26 \\
45 \\
125\end{array}$ & $\begin{array}{l}12 \\
12 \\
37 \\
142\end{array}$ & $\begin{array}{l}0.96(0.4 I-2.25) \\
0.4 I(0.19-0.84) \\
0.72(0.44-1.19) \\
\mathrm{I}\end{array}$ & $\begin{array}{l}0.926 \\
0.015^{*} \\
0.202^{*}\end{array}$ \\
\hline $\begin{array}{l}\text { Educational } \\
\text { status }\end{array}$ & $\begin{array}{l}\text { Unable to read and write } \\
\text { Read and write } \\
\text { First cycle (Grade 1-4) } \\
\text { Second cycle (Grade 5-8) } \\
\text { High school and preparatory (Grade 9-12) } \\
\text { Tertiary education (Above Grade 12) }\end{array}$ & $\begin{array}{l}10 \\
20 \\
23 \\
93 \\
44 \\
17\end{array}$ & $\begin{array}{l}10 \\
14 \\
18 \\
73 \\
67 \\
21\end{array}$ & $\begin{array}{l}0.81(0.27-2.40) \\
0.57(0.22-1.44) \\
0.63(0.26-1.54) \\
0.64(0.31-1.29) \\
1.23(0.59-2.59) \\
1\end{array}$ & $\begin{array}{l}0.703 \\
0.234^{*} \\
0.314 \\
0.210^{*} \\
0.582\end{array}$ \\
\hline $\begin{array}{l}\text { Occupation } \\
\text { status }\end{array}$ & $\begin{array}{l}\text { Jobless } \\
\text { House wife } \\
\text { Student } \\
\text { Day laborer } \\
\text { Private employ } \\
\text { Government employee } \\
\text { Merchant }\end{array}$ & $\begin{array}{l}6 \\
28 \\
22 \\
37 \\
63 \\
17 \\
34\end{array}$ & $\begin{array}{l}8 \\
22 \\
23 \\
30 \\
68 \\
32 \\
20\end{array}$ & $\begin{array}{l}2.27(0.69-7.48) \\
1.34(0.61-2.93) \\
1.78(0.79-3.97) \\
1.38(0.66-2.87) \\
1.84(0.96-3.52) \\
3.20(1.43,-7.17) \\
1\end{array}$ & $\begin{array}{l}0.177^{*} \\
0.470 \\
0.161^{*} \\
0.391 \\
0.067^{*} \\
0.005^{*}\end{array}$ \\
\hline $\begin{array}{l}\text { Average } \\
\text { monthly } \\
\text { income (ETB) }\end{array}$ & $\begin{array}{l}\leq 500 \\
50 I-1000 \\
1001-1500 \\
\geq 1501\end{array}$ & $\begin{array}{l}118 \\
41 \\
7 \\
41\end{array}$ & $\begin{array}{l}97 \\
37 \\
10 \\
59\end{array}$ & $\begin{array}{l}0.57(0.35-0.93) \\
0.63(0.35-1.14) \\
0.99(0.35-2.82) \\
I\end{array}$ & $\begin{array}{l}0.022)^{*} \\
0.125^{*} \\
0.989\end{array}$ \\
\hline CD4 count (cells/mm $\left./ \mathrm{mm}^{3}\right)$ & $\begin{array}{l}\leq 350 \\
351-1000 \\
>1000\end{array}$ & $\begin{array}{l}87 \\
111 \\
9\end{array}$ & $\begin{array}{l}73 \\
117 \\
13\end{array}$ & $\begin{array}{l}0.58(0.24-1.44) \\
0.73(0.30-1.78) \\
\mathrm{I}\end{array}$ & $\begin{array}{l}0.239 * \\
0.487\end{array}$ \\
\hline $\begin{array}{l}\text { Viral load ( } \\
\text { copies/dL) }\end{array}$ & $\begin{array}{l}>1000 \\
\leq 1000\end{array}$ & $\begin{array}{l}36 \\
|7|\end{array}$ & $\begin{array}{l}45 \\
158\end{array}$ & $\begin{array}{l}1.35(0.83-2.21) \\
\mathrm{I}\end{array}$ & $0.226^{*}$ \\
\hline $\begin{array}{l}\text { WHO HIVIAIDS } \\
\text { stage }\end{array}$ & $\begin{array}{l}\text { Stage IV } \\
\text { Stage III } \\
\text { Stage II } \\
\text { Stage I }\end{array}$ & $\begin{array}{l}10 \\
26 \\
9 \\
162\end{array}$ & $\begin{array}{l}5 \\
18 \\
11 \\
169\end{array}$ & $\begin{array}{l}0.48(0.16-1.43) \\
0.66(0.35-1.26) \\
1.17(0.47-2.90) \\
\mathrm{I}\end{array}$ & $\begin{array}{l}0.188^{*} \\
0.208^{*} \\
0.732\end{array}$ \\
\hline $\begin{array}{l}\text { Opportunistic } \\
\text { infection }\end{array}$ & $\begin{array}{l}\text { Yes } \\
\text { No }\end{array}$ & $\begin{array}{l}62 \\
145\end{array}$ & $\begin{array}{l}84 \\
119\end{array}$ & $\begin{array}{l}1.65(1.10-2.48) \\
\mathrm{I}\end{array}$ & $0.016)^{*}$ \\
\hline Adherence & $\begin{array}{l}\text { Poor } \\
\text { Fair } \\
\text { Good }\end{array}$ & $\begin{array}{l}60 \\
25 \\
122\end{array}$ & $\begin{array}{l}90 \\
16 \\
97\end{array}$ & $\begin{array}{l}\text { I.89 }(1.24-, 2.88) \\
0.81(0.41-1.59) \\
\mathrm{I}\end{array}$ & $\begin{array}{l}0.003^{*} \\
0.533\end{array}$ \\
\hline $\begin{array}{l}\text { CPT } \\
\text { prophylaxis }\end{array}$ & $\begin{array}{l}\text { Yes } \\
\text { No }\end{array}$ & $\begin{array}{l}74 \\
133\end{array}$ & $\begin{array}{l}57 \\
146\end{array}$ & $\begin{array}{l}0.70(0.46-1.07) \\
\mathrm{I}\end{array}$ & $0.096 *$ \\
\hline Social stigma & $\begin{array}{l}\text { High } \\
\text { Low }\end{array}$ & $\begin{array}{l}49 \\
158\end{array}$ & $\begin{array}{l}76 \\
127\end{array}$ & $\begin{array}{l}1.93(1.26-2.96) \\
1\end{array}$ & $0.003^{*}$ \\
\hline
\end{tabular}

Note: ${ }^{*} p$-value $<0.25$ 
Table 4 Significantly Associated Factors with Depression in PLWHA at Wolaita Sodo University Teaching and Referral Hospital ART Clinic, $2019(n=410)$

\begin{tabular}{|c|c|c|c|c|c|c|}
\hline \multirow[t]{2}{*}{ Characteristics } & \multirow[t]{2}{*}{ Category } & \multicolumn{2}{|c|}{ Depression } & \multirow[t]{2}{*}{ COR $(95 \% \mathrm{Cl})$} & \multirow[t]{2}{*}{ AOR (95\%Cl) } & \multirow[t]{2}{*}{$p$-value } \\
\hline & & Yes & No & & & \\
\hline Sex & $\begin{array}{l}\text { Male } \\
\text { Female }\end{array}$ & $\begin{array}{l}79 \\
128\end{array}$ & $\begin{array}{l}98 \\
105\end{array}$ & $\begin{array}{l}1.5 \mathrm{I}(1.02-2.24) \\
\mathrm{I}\end{array}$ & $\begin{array}{l}1.53(|.02-2.3|) \\
1\end{array}$ & $0.042^{*}$ \\
\hline Residence & $\begin{array}{l}\text { Urban } \\
\text { Rural }\end{array}$ & $\begin{array}{l}155 \\
52\end{array}$ & $\begin{array}{l}175 \\
28\end{array}$ & $\begin{array}{l}2.10(1.26-3.48) \\
1\end{array}$ & $\begin{array}{l}2.21(1.30-3.75) \\
I\end{array}$ & $0.003^{* *}$ \\
\hline OI & $\begin{array}{l}\text { Yes } \\
\text { No }\end{array}$ & $\begin{array}{l}62 \\
145\end{array}$ & $\begin{array}{l}84 \\
119\end{array}$ & $\begin{array}{l}1.65(1.10-2.48) \\
1\end{array}$ & $\begin{array}{l}1.99(1.27-3.11) \\
1\end{array}$ & $0.003 * *$ \\
\hline Adherence & $\begin{array}{l}\text { Poor } \\
\text { Fair } \\
\text { Good }\end{array}$ & $\begin{array}{l}60 \\
25 \\
122\end{array}$ & $\begin{array}{l}90 \\
16 \\
97\end{array}$ & $\begin{array}{l}1.89(1.24-2.88) \\
0.81(0.4 I-1.59) \\
1\end{array}$ & $\begin{array}{l}I .79(1.13-2.85) \\
0.54(0.26-1.15) \\
\text { I }\end{array}$ & $\begin{array}{l}0.013^{*} \\
0.108\end{array}$ \\
\hline Perceived stigma & $\begin{array}{l}\text { High } \\
\text { Low }\end{array}$ & $\begin{array}{l}49 \\
158\end{array}$ & $\begin{array}{l}76 \\
127\end{array}$ & $\begin{array}{l}1.93(1.26-2.96) \\
1\end{array}$ & $\begin{array}{l}1.67(1.04-2.67) \\
\text { । }\end{array}$ & $0.034^{*}$ \\
\hline
\end{tabular}

Notes: Significant association ${ }^{*} p$-value $<0.05$ and $*^{*} p$-value $<0.0$ I; $n$, sample size; I, reference.

to drug. Furthermore, HIV/AIDS becomes complicated and the patients became depressed. ${ }^{10}$

Patients who had high HIV-related perceived stigma were about 1.6 times more likely to develop depression than patients who had low HIV-related perceived stigma. The finding is similar to studies conducted in Debrebiran and East Africa. ${ }^{11,28}$ This might be due to the fact that people with chronic lifelong diseases might not have the interest to participate in social issues. Stigma might result in delay in seeking HIV/ AIDS treatment, poor retention in follow-up and poor ART adherence, which might result in depression. Therefore, proper handling of depression is an important component to prevent and control HIV/AIDs transmission.

\section{Conclusion and Recommendations}

In this study, nearly half of the patients in the ART clinic were depressed. Male, urban residents, opportunistic infections, poor medication adherence, and high HIV-related perceived stigma were significantly associated with depression. Although the burden of depression is high among HIV-positive patients, it is underdiagnosed and undertreated in the ART clinic. So, health facility should give due attention and priority to those patients with depressive symptoms. Researchers should conduct prospective design studies to get better findings.

\section{Limitations}

The reported level of depression might be under- or overreported because it is based on self report. The other limitation is not using a structured clinical interview for diagnosis of depression.

\section{Abbreviations}

AOR, adjusted odds ratio; ART, antiretroviral therapy; $\mathrm{ARV}$, antiretroviral; CD4, cluster of differentiation 4; COR, crude odds ratio; CPT, cotrimoxazole preventive therapy; ETB, Ethiopian birr; HAART, highly active antiretroviral therapy; INH, isoniazid; PHQ, patient health questionnaires; PLWHA, people living with HIV/AIDS; SNNP, Southern Nation Nationalities People; SPSS, Statistical Package for the Social Sciences.

\section{Data Sharing Statement}

The data that support the findings of this study are available but some restrictions may apply to the availability of these data as there are some sensitive issues. However, data are available from the corresponding author upon reasonable request.

\section{Ethics Approval and Consent to Participate}

The data collection was carried out after approval by the Ethical Committee of the College of Health Sciences and Medicine, Wolaita Sodo University. The study was 
conducted based on voluntary participation by study subjects after explaining the purpose of study. All the information accessed from study participants was kept confidential. All participants provided informed consent to participate in this study, and parental informed consent was obtained for participants under the age of 18 in accordance with the Declaration of Helsinki.

\section{Acknowledgments}

We would like to thank Wolata Sodo University for giving this chance to conduct this study.

We would also like to take this opportunity to thank supervisors and data collectors for their commitment during data collection as well as respondents for their willingness to give important data which was essential for the study.

\section{Author Contributions}

TB coordinated the overall research activities and analyzed the data in software, WF and TM participated in data analysis and statistical techniques, AB participated in methodological part of the study and manuscript preparation. All the authors have read and approved the final version of this manuscript. All authors made substantial contributions to conception and design, acquisition of data, or analysis and interpretation of data; took part in drafting the article or revising it critically for important intellectual content; agreed to submit to the current journal; gave final approval of the version to be published; and agree to be accountable for all aspects of the work.

\section{Funding}

There is no funding to report.

\section{Disclosure}

The authors report no conflicts of interest in this work.

\section{References}

1. World Health Organization. International Statistical Classification of Diseases and Related Health Problems. 10th ed. Geneva, Switzerland: World Health Organization; 2010:240-261.

2. Burns JK. Mental health challenges related to HIV-AIDS in developing countries. JPPS. 2012;9:3-4.

3. Akena DH, Musisi S, Kinyanda E. A comparison of the clinical features of depression in HIV- positive and HIV-negative patients in Uganda. Afr $J$ Psychiatry. 2010;13:43 \pm 51 . doi:10.4314/ajpsy. v13i1.53429

4. P SC M, Etienne-Mesubi M, Agbor S, et al. The effect of depressive symptoms and CD4 count on adherence to highly active antiretroviral therapy in sub-Saharan Africa. $J$ Int Assoc Provid AIDS Care. 2014; $13: 346 \pm 52$.
5. WHO. HIV-AIDS and mental health. WHO; 2008 (Internet). Accessed February 23, 2017.

6. WHO. Suicide prevention (Internet). Available from: http://wwwwhoint/ mental_health/suicide- prevention/en/. Accessed January 20, 2017.

7. Uthman OA, Magidson JF, Safren SA, Nachega JB. Depression and adherence to antiretroviral therapy in low-, middle- and high-income countries: a systematic review and meta-analysis. Curr HIV/AIDS Rep. 2014;11:291-307. doi:10.1007/s11904-014-0220-1

8. Morrison SD, Banushi VH, Sarnquist C, Gashi VH, Osterberg L, Maldonado Y. Levels of self-reported depression and anxiety among HIV-positive patients in Albania: a cross-sectional study. Croat Med J. 2011;52(5):622-628. doi:10.3325/cmj.2011.52.622

9. Silveira MP, Guttier MC, Pinheiro CA, Pereira TV, Cruzeiro AL, Moreira LB. Depressive symptoms in HIV-infected patients treated with highly active antiretroviral therapy. Revistabrasileira De Psiquiatria. 2012;34(2):162-167.

10. Gelaye B, Williams MA, Lemma S, et al. Validity of the patient health questionnaire-9 for depression screening and diagnosis in East Africa. Psychiatry Res. 2013;210(2):653-661. doi:10.1016/j. psychres.2013.07.015

11. Genberg BL, Hlavka Z, Konda KA, et al. A comparison of HIV/ AIDS-related stigma in four countries: negative attitudes and perceived acts of discrimination towards people living with HIV/AIDS. Soc Sci Med. 2009;68:2279-2287. doi:10.1016/j.socscimed.2009.04.005

12. Kocalevent R-D, Berg L, Beutel ME, et al. Social support in the general population: standardization of the Oslo social support scale (OSSS-3). BMC Psychol. 2018;6:31. doi:10.1186/s40359-018-0249-9

13. National consolidated guidelines for comprehensive HIV prevention, care and Treatement. 2018

14. Duko B, Geja E, Zewude M, Mekonen S. Prevalence and associated factors of depression among patients with HIV/AIDS in Hawassa, Ethiopia, cross-sectional study. Ann Gen Psychiatry. 2018;17:45. doi:10.1186/s12991-018-0215-1

15. Molla GL, Sebhat HM, Hussen ZN, et al. Depression among Ethiopian adults: cross-sectional study. Psychiatry J. 2016;2016. doi: $10.1155 / 2016 / 1468120$

16. Dal-Bó MJ, Manoel MAL, Filho AOB, et al. Depressive symptoms and associated factors among people living with HIV/AIDS. $J$ Int Assoc Provid AIDS Care (JIAPAC). 2015;14(2):136-140. doi:10.1177/2325957413494829

17. Wang T, Fu H, Kaminga AC, et al. Prevalence of depression or depressive symptoms among people living with HIV/AIDS in China: a systematic review and meta-analysis. BMC Psychiatry. 2018;18:160. doi:10.1186/s12888-018-1741-8

18. Mohammed M, Mengistie B, Dessie Y, et al. Prevalence of depression and associated factors among HIV patients seeking treatments in ART clinics at Harar Town, Eastern Ethiopia. J AIDS Clin Res. 2015;6:2.

19. Elbadawi A, Mirghani H. Depression among HIV/AIDS Sudanese patients: a cross-sectional analytic study. Pan Afr Med J. 2017;26. doi:10.11604/pamj.2017.26.43.10919

20. Alvi Y, Khalique N, Ahmad A, Khan HS, Faizi N. Prevalence of depression among HIV- positive patients treated with antiretrovirals at different stage of infection. HIV AIDS Rev. 2018;17(4):243-248. doi:10.5114/hivar.2018.80255

21. Thadar M, Boonyleepun S, Khaing C, Laohasilwong W. Prevalence of depression and its associated factors among PLHIVs attending the Public ART centers, Yangon region, Myanmar. Ann Trop Med Public Health. 2017;10(1):216-221. doi:10.4103/1755-6783.205589

22. Clarke T, Gibson R, Barrow G, Abel W, Barton E. Depression among persons attending a HIV/AIDS outpatient clinic in Kingston, Jamaica. West Indian Med. 2010;59(4):369.

23. Ngum PA, Fon PN, Ngu RC, Verla VS. Depression among HIV/ AIDS patients on highly active antiretroviral therapy in the Southwest regional hospitals of Cameroon: a cross-sectional study. Neurol Ther. 2017;6:103-114. doi:10.1007/s40120-017-0065-9 
24. Kim HM, Mazenga AC, Yu X, et al. Factors associated with depression among adolescents living with HIV in Malawi. BMC Psychiatry. 2015;15:264. doi:10.1186/s12888-015-0649-9

25. Amare T, Getinet W, Shumet S, Asrat B. Prevalence and associated factors of depression among PLHIV in Ethiopia: systematic review and meta-analysis. AIDS Res Treat. 2018;2017:9.

26. Berhe H, Bayray A. prevalence of depression and associated factors among people living with hiv/aids in tigray,northethiopia: a cross sectional hospital based study. Int J Pharm Sci Res. 2013;4 (2):765-775.

27. Kibret GD, Salilih SZ. Prevalence and associated factors of depression among HIV infected patients in Debre Markos Town Northwest Ethiopia. Int J Emerg Ment Health. 2015;17(4):714-716.
28. Eshetu DA, MeseretWoldeyohannes S, AlemayehuKebede M, et al Prevalence of depression and associated factors among HIV/AIDS patients attending ART clinic at Debrebirhan referral hospital,North Showa, Amhara Region,Ethiopia. iMedPub. 2015;1(1):37.

29. Wondatir BC, Abdel Menan S. Prevalence and associated factors of depression among HIV positive clients at Yekatit 12 hospital medical college, Addisababa, Ethiopia. Proceedings of 103rd ISERD International Conference; 20th-21st, 2018; Los Angles, USA.

30. Nyirenda M, Chatterji S, Rochat T, et al. Prevalence and correlates of depression among HIV-infected and - affected older people in rural South Africa. J Affect Disord. 2013;151:31-38. doi:10.1016/j. jad.2013.05.005

HIV/AIDS - Research and Palliative Care

\section{Publish your work in this journal}

HIV/AIDS - Research and Palliative Care is an international, peerreviewed open-access journal focusing on advances in research in HIV, its clinical progression and management options including antiviral treatment, palliative care and public healthcare policies to control viral spread. The manuscript management system is completely online and includes a very quick and fair peer-review system, which is all easy to use. Visit http://www.dovepress.com/testimonials.php to read real quotes from published authors. 